Кривобок К. В., к.е.н. Харківський начіональний економічний університет імені Семена Кузнеия м. Харків, Украӥна

DOI: https://doi.org/10.30525/978-9934-26-028-5-32

\title{
ОСОБЛИВОСТІ УПРАВЛІННЯ ПРОЦЕСАМИ АДАПТАЦІЇ В СУЧАСНИХ УМОВАХ РОЗВИТКУ ЕКОНОМІКИ
}

Високий рівень динамізму та невизначеності зовнішнього середовища в сучасних умовах глобалізації, недосконалість методів управління, зокрема у прийняті обгрунтованих управлінських рішень за короткий термін, призводить до негативних тенденцій, які простежуються у ключових показниках діяльності вітчизняних підприємств. Саме адаптація є тим інструментом, який може забезпечити збалансованість внутрішнього стану суб'єкту господарювання до мінливих вимог зовнішнього середовища, що потребує удосконалення існуючого механізму управління підприємством на всіх рівнях ієрархій та впровадити окремі елементи адаптивного керування. Проведені дослідження доводять не тільки важливість, але й необхідність організації управління процесами адаптації промислових підприємств галузі машинобудування на постійній основі.

В умовах нестабільного середовища, підвищення конкуренції на світових ринках та глобалізації перед вітчизняними підприємствами гостро виникла проблема застосування ефективної системи управління. Сучасна парадигма управління підприємством, яка забезпечить їм конкурентоспроможність та розвиток, повинна бути системною, зосереджена на створенні стратегічних активів підприємства та заснована на підході, що забезпечить швидку адаптацію в умовах мінливості зовнішніх факторів завдяки ефективному використанню власного потенціалу та наявних ресурсів.

Аналіз останніх досліджень і публікацій довів, що розробкою ефективних інструментів управління підприємством в умовах 
нестабільного середовища закордонні та вітчизняні вченні займаються багато років, багато уваги приділяється обгрунтуванню основних принципів, яких необхідно дотримуватись при стратегічному управлінні підприємством. Згідно аналізу літературних джерел $[1 ; 2 ; 3 ; 4]$ провідні підприємства використовують різні інструменти менеджменту для вирішення поточних та стратегічних питань, а саме: аналіз діяльності підприємства для визначення його поточного положення у зовнішньому середовищі; формулювання загроз та можливостей; аналіз впливу чинників зовнішнього середовища; уточнення цілей і завдань підприємства; розробка стратегій діяльності відповідно можливим сценаріям; обгрунтування управлінських рішень і т.ін.

Використання результатів діагностики та аналізу показників із застосуванням інструментів менеджменту забезпечить найбільш ефективний зв'язок між всіма елементами керованої системи. Для управління процесами адаптації промислових підприємств до зовнішнього середовища ми візьмемо за основу загальні підходи по М. Портеру [3]: лідерство у витратах; диференціація продукції; фокусування або концентрація; ранній вихід на ринок/стратегія першопрохідника та синергізм. Але, сьогодні підприємство функціонує в умовах швидких змін у зовнішньому середовищі і тому для вирішення поточних власних проблем має застосовувати власні набори відповідних заходів. Оперативне реагування на тенденції змін у конкурентному середовищі та ефективне стратегічне маневрування підприємства забезпечується впровадженням системи раннього виявлення конкретного сценарію на основі застосування визначених показників. Слід зауважити, що розробка сценаріїв розвитку підприємства тісно пов'язане з його стратегічним плануванням.

Розробка ефективної бізнес-моделі перспективного розвитку підприємства потребує розуміння його керівництвом поточної ситуації на ринку й максимального врахування впливу зовнішніх та внутрішніх факторів, що повинно грунтуватись на достовірній інформації. Послідовність дій та методи, які на нашу думку забезпечать отримання реальних показників необхідних для 
оперативного управління підприємством, тобто етапи реалізації методичного підходу до управління процесами адаптації промислового підприємства до зовнішнього середовища наведено на рис. 1 на основі вивчення роботи [4].

Складність прийняття управлінських рішень обумовлює ланцюг потрібних певних дій для їх обгрунтування (рис. 1). На першому етапі необхідно здійснити прогноз реального обсягу відповідного сегменту ринку товарів або надання послуг 3 урахуванням впливу зовнішніх факторів та ризиків. Для вирішення цих завдань пропонуємо використовувати MVC-аналіз і MaRis-аналіз. Застосування цих методів передбачає комплексний аналіз зовнішніх та внутрішніх факторів, які впливатимуть на діяльність підприємства у визначеному інтервалі часу.
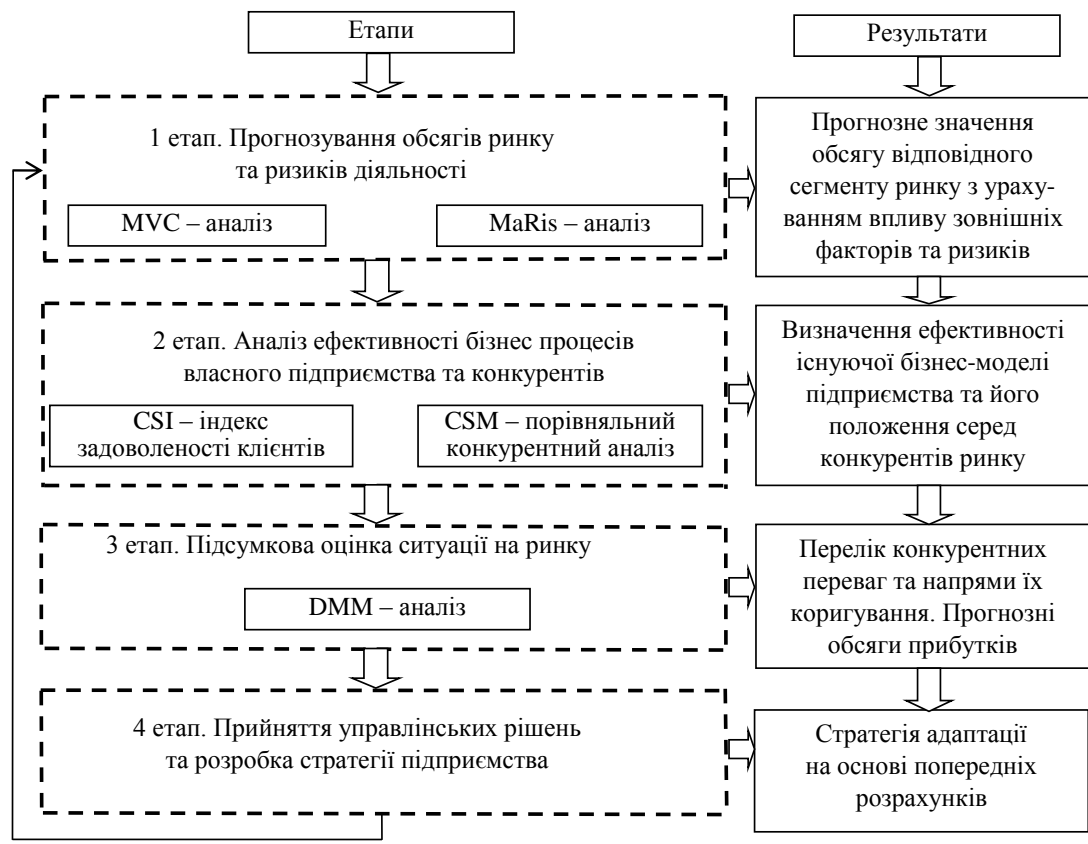

Рис. 1. Етапи реалізації методичного підходу до управління процесами адаптації промислового підприсмства до зовнішнього середовища 
Важливим для якісного стратегічного планування розвитку промислового підприємства $\epsilon$ оцінка ефективності власних бізнес-процесів та їх порівняння з аналогічними у конкурентів, що виконується на другому етапі. Це передбачає розрахунок індексу задоволеності клієнтів (CSI) та порівняльний конкурентний аналіз (CSM). Третій етап передбачає підсумкову оцінку ситуації на ринку 3 отриманням показників, які надають можливість визначити ефективність існуючої бізнес-моделі підприємства, доцільність іï використання у наступному періоді або потребу корегування, розрахувати прогнозовані прибутки i т.ін. Для вирішення цього завдання пропонується застосовувати метод DMМ-аналізу [3].

Останній четвертий етап - це прийняття управлінського рішення щодо стратегічного розвитку підприємства у визначеному періоді та розробка стратегії на основі отриманих даних від попередніх розрахунків. Динамічне середовище вимагає від підприємств застосування сучасного підходу в управлінні, що передбачає формування програм стратегічного розвитку i на їх основі проектів, які $є$ інструментами адаптації до мінливості зовнішнього середовища. Розробка та реалізація програм перетворення в організації має ієрархічний характер. На основі аналізу ринкової ситуації визначається поточний рівень конкурентних переваг організації і встановлюється період часу, коли ці переваги досягнуть критичного рівня. До цього моменту часу організація повинна реалізувати конкретну стратегічну програму з адаптації до нових умов господарювання [4]. Для цього необхідно реалізувати ряд заходів, що мають чітку мету, терміни, обмежені ресурси, що за основними ознаками відповідає визначенню проекту. Створені елементи управління процесами адаптації підприємства відповідно тенденціям змін зовнішнього середовища повинні бути інтегровані в організаційну структуру підприємства та мати різні завдання відповідно до їх функцій. Визначальним для ефективного функціонування $є$ розуміння керівництвом жорсткої структури інформаційних потоків, які виконують дві основні функції - це забезпечення зв'язку ієрархічної лінії та функціональних зв'язків. 
Отримана інформація по каналах зворотного зв'язку використовується для корегування впливу на суб'єкт управління, що передбачає зміну параметрів, структури, алгоритмів дії системи, критеріїв, можливість самонавчання та зміни типу стратегії, що має забезпечити досягнення динамічної рівноваги системи.

Важливим є розмежування процесу адаптації з іншими процесами, які забезпечують операційну діяльність підприємства. Основне завдання для фахівців відповідальних за адаптацію - це вироблення і реалізація стратегічних завдань на основі результатів моніторингу зовнішнього середовища та діагностики внутрішнього стану підприємства, аналізі тенденцій змін та кон'юнктури ринку в оперативній та довгостроковій перспективі.

\section{Література:}

1. Ансофф И. Стратегическое управление / Сокр. пер. с англ.; науч. ред. и авт. предисл. Л.И. Евенко. Москва : Экономика, 1989. 519 с.

2. Коломієць І.Ф., Гошовська Г.В. Еволюція теорій інноваційно-технологічного розвитку в ретроспективній оцінці. Регіональна економіка. 2014. № 2. C. $178-186$.

3. Портер М. Конкурентная стратегия: Методика анализа отраслей и конкурентов / пер. с англ.; 3-е изд. Москва : Альпина Бизнес Букс, 2007. 453 с.

4. Маркіна I.А., Аранчій В.І., Сафронов Ю.М., Лепейко Т.І. та інш. Менеджмент XXI століття: глобалізацій ні виклики: монографія / за ред. I.А. Маркіної. Полтава : Видавництво «Сімон», 2017. 728 с. 